Brit. F. vener. Dis. (1967), 43, 75.

\title{
ACTION OF THREE DRUG COMBINATIONS ON GONOCOCCI*
}

\author{
BY \\ L. P. GARROD AND PAMELA M. WATERWORTH \\ Department of Bacteriology, Royal Postgraduate Medical School, London
}

Resistance to penicillin in gonococci is slowly but apparently steadily increasing in both frequency and degree. The desirability of effective alternative treatment is widely recognized, and therapeutic studies have been carried out with a variety of other antibiotics with varying but never complete success. Resistance to some of these, such as streptomycin and tetracycline, is known to be capable of developing less slowly than that to penicillin.

In these circumstances it is natural to turn to combinations of anti-bacterial drugs for two reasons: they are sometimes more effective than either drug acting alone, and their simultaneous presence is a strong deterrent to the change, whether adaptive or mutational, leading to increased resistance to either. This paper examines the merits of three such combinations as determined by laboratory methods.

Combined action may be of four kinds, for which the following terms and definitions are adopted here:

(1) Indifferent Neither drug contributes to the action of the other.

(2) Additive A combination of individually subeffective concentrations is effective, but one of these is not much lower (one half in the usual series) than that effective alone.

(3) Synergic A combination of concentrations is effective which is much lower than those required when acting alone.

(4) Antagonistic The presence of a second drug reduces the activity of the other.

Examples of the first three kinds of action have been seen in the experiments described.

\section{Material and Methods}

The strains of $N$. gonorrhoeae used in the experiments with trimethoprim were isolated at St. Mary's Hospital during a therapeutic trial of this drug and kindly supplied

* Received for publication September 14, 1967. to us by $\operatorname{Dr}$ S. R. M. Bushby. Those used in the experiments with kanamycin were isolated by Dr Rosemary Simon at the Middlesex Hospital and kindly furnished to us by her.

Trimethoprim was supplied by the Wellcome Foundation and pure sulphafurazole powder by Roche Products Ltd.

Minimum inhibitory concentrations (MIC) were determined by the plate dilution method. In the experiments with kanamycin and penicillin the medium was Oxoid Blood Agar Base No. 2 with 6 per cent. horse blood heated to $80^{\circ} \mathrm{C}$. In the experiments with trimethoprim and kanamycin with sulphafurazole, the medium was Oxoid Diagnostic Sensitivity Test Agar Base with 6 per cent. horse blood heated to $80^{\circ} \mathrm{C}$. The drug solutions were added in a volume of $1 \mathrm{ml}$. to $19 \mathrm{ml}$. of medium. The plates were inoculated from 48-hour "chocolate" broth cultures diluted approximately $1: 100$ by means of a multiple inoculator, and incubated in candle jars for $\mathbf{4 8}$ hours.

For tests of bactericidal action $200 \mathrm{ml}$. "chocolate" broth (Oxoid Tryptone Soya Broth plus 6 per cent. horse blood heated to $80^{\circ} \mathrm{C}$.) were inoculated with $4 \mathrm{ml}$. of a 48-hour culture in the same medium, and tubed in $4 \mathrm{ml}$. amounts, to which drug solutions in broth were added in a volume of $0.5 \mathrm{ml}$. In experiments with sulphafurazole, the blood was lysed before addition and the broth incubated overnight before heating. These cultures were placed in a water bath at $37^{\circ} \mathrm{C}$. and at intervals a $2 \mathrm{~mm}$. loopful was spread over a segment of a plate containing Blood Agar Base No. 2 plus 6 per cent. heated blood. These were incubated in candle jars for $\mathbf{4 8}$ hours.

\section{Drug Combinations \\ Kanamycin and Penicillin}

Gonococci are uniformly sensitive to kanamycin, although not very highly so: the usual minimum inhibitory concentration is $4 \mu \mathrm{g}$. $/ \mathrm{ml}$. Acute gonorrhoea has been treated with kanamycin with a high proportion of successes (Wilkinson, Race, and Curtis, 1967; Hooton and Nicol, 1967), but it has been found that the single dose given should be one of $2 \mathrm{~g}$. 
This large amount involves a remote risk of ototoxicity, at least in patients with unrecognized impairment of renal function, but its main disadvantage, were this antibiotic to be used extensively, is cost. The possibility that a smaller dose combined with one of penicillin might be equally or even more effective seemed, therefore, worth exploring. That the effect might even be better is suggested by the fact that combinations of two antibiotics both of which are bactericidal often act synergically. Such a synergic effect has been demonstrated most clearly for combinations of a penicillin with one of the aminoglycosides (streptomycin, neomycin, kanamycin, etc.), which are recognized as the only effective means for treating Streptococcus faecalis endocarditis, in which a total bactericidal effect is essential.

\section{Bacteristatic Tests}

The MIC of the two antibiotics for the 23 strains examined are stated in Table I. It will be seen that they exhibited a representative range of degrees of sensitivity to penicillin, but a much more nearly constant sensitivity to kanamycin.

TABLE I

NUMBER OF STRAINS INHIBITED BY DIFFERENT CONCENTRATIONS OF PENICILLIN OR KANAMYCIN

\begin{tabular}{|c|c|c|c|c|c|c|c|c|c|}
\hline \multirow{2}{*}{ Drug } & \multicolumn{9}{|c|}{ Concentration ( $\mu \mathrm{g} . / \mathrm{ml})}$. \\
\hline & 8 & 421 & 10.5 & $0 \cdot 25$ & 0.12 & 0.06 & 0.03 & 0.015 & 0.007 \\
\hline Penicillin & & & 2 & 1 & 5 & 3 & - & 6 & 6 \\
\hline Kanamycin & & 148 & & & & & & & \\
\hline
\end{tabular}

Three typical results of tests of combined action are given in Table II. The effect on Strain 1 is indifferent: neither antibiotic contributes to the action of the other, the MIC being the same despite the presence of the other in any concentration below its own MIC. This type of effect was seen with six strains, five of which were among those less sensitive to penicillin. All the remainder showed minor degrees of an additive effect, typified by Strains 2 and 3 in Table II.

\section{Tests of Bactericidal Action}

These laborious tests were carried out with two strains with results shown in Table III (opposite). As well as the findings given at 4,6 , and 24 hours, platings were made at 2 and 3 hours and showed little reduction from the zero counts. Kanamycin alone was bactericidal at twice its MIC for both strains, and penicillin alone at four times its MIC for one of them, but not at all for the less sensitive strain. The combination exerted an additive effect: in all instances the concentrations combining to sterilize the inoculum were half those required to do so alone, except that $1 \mu \mathrm{g} . / \mathrm{ml}$. of each killed Strain 21 in 24 hours.

\section{Kanamycin and Sulphafurazole}

When penicillin became available for treating gonorrhoea most strains of gonococci in some areas were sulphonamide-resistant. With the abandonment of sulphonamides for treating the disease the organism reverted to sensitivity: Cradock-Watson, Shooter, and Nicol (1958), for instance, studying the emergence of penicillin resistance, found all but one of their 200 strains sulphonamide-sensitive, and the situation at the present day is similar. No one would suggest that sulphonamides alone be reintroduced for treatment, but there seemed to be some interest in knowing how a combination of a sulphonamide with kanamycin would behave.

Bacteristatic tests only were done with thirteen strains, and the results are stated in condensed form in Table IV. The last column gives the combinations of lowest concentrations which prevented growth.

TABLE II

GROWTH OF THREE STRAINS OF $N$. GONORRHOEAE ON MEDIUM CONTAINING PENICILLIN AND KANAMYCIN

\begin{tabular}{|c|c|c|c|c|c|c|c|c|c|c|c|c|c|c|c|c|c|c|c|}
\hline & & \multicolumn{18}{|c|}{ Kanamycin $(\mu \mathrm{g} . / \mathrm{ml})}$. \\
\hline & & \multicolumn{6}{|c|}{1} & \multicolumn{6}{|c|}{2} & \multicolumn{6}{|c|}{3} \\
\hline & & 4 & 2 & 1 & 0.5 & $0 \cdot 25$ & Nil & 4 & 2 & 1 & 0.5 & 0.25 & Nil & 4 & 2 & 1 & 0.5 & $0 \cdot 25$ & $\mathrm{Nil}$ \\
\hline $\begin{array}{l}\text { Penicillin } \\
\mu \mathrm{g} . / \mathrm{ml} \text {. }\end{array}$ & $\begin{array}{l}0.5 \\
0.25 \\
0.12 \\
0.06 \\
0.03 \\
0.015 \\
0.007 \\
0.003 \\
0.0015 \\
\text { Nil }\end{array}$ & $\begin{array}{l}\overline{-} \\
\overline{-} \\
\overline{-} \\
\overline{-} \\
\overline{-} \\
\overline{-}\end{array}$ & $\begin{array}{l}- \\
\overline{+} \\
++ \\
++ \\
++ \\
++ \\
++ \\
++ \\
++\end{array}$ & $\begin{array}{l}- \\
- \\
++ \\
++ \\
++ \\
++ \\
++ \\
++ \\
++ \\
++\end{array}$ & $\begin{array}{l}- \\
- \\
++ \\
++ \\
++ \\
++ \\
++ \\
++ \\
++ \\
++\end{array}$ & $\begin{array}{l}- \\
- \\
++ \\
++ \\
++ \\
++ \\
++ \\
++ \\
++ \\
++\end{array}$ & $\begin{array}{l}- \\
- \\
++ \\
++ \\
++ \\
++ \\
++ \\
++ \\
++ \\
++\end{array}$ & $\begin{array}{l}- \\
- \\
\overline{-} \\
- \\
\overline{-} \\
- \\
-\end{array}$ & $\begin{array}{c}- \\
- \\
- \\
= \\
\overline{+} \\
+ \\
++ \\
++ \\
++\end{array}$ & $\begin{array}{l}\overline{-} \\
\overline{-} \\
\overline{-} \\
\overline{+} \\
++ \\
++ \\
++ \\
++\end{array}$ & $\begin{array}{l}- \\
\overline{-} \\
\overline{+} \\
+ \\
++ \\
++ \\
++ \\
++ \\
++\end{array}$ & $\begin{array}{l}- \\
\overline{-} \\
\overline{-} \\
++ \\
++ \\
++ \\
++ \\
++ \\
++\end{array}$ & $\begin{array}{l}- \\
- \\
\overline{-} \\
++ \\
++ \\
++ \\
++ \\
++ \\
++\end{array}$ & $\begin{array}{l}- \\
\overline{-} \\
\overline{-} \\
\overline{-} \\
\overline{-} \\
-\end{array}$ & $\begin{array}{l}- \\
- \\
= \\
- \\
- \\
- \\
+ \\
+\end{array}$ & $\begin{array}{l}- \\
= \\
= \\
= \\
\overline{+} \\
+ \\
++ \\
++\end{array}$ & $\begin{array}{l}- \\
\overline{-} \\
\overline{-} \\
\overline{+} \\
+ \\
++ \\
++\end{array}$ & $\begin{array}{l}- \\
- \\
= \\
- \\
- \\
++ \\
++ \\
++ \\
++\end{array}$ & $\begin{array}{l}- \\
- \\
= \\
- \\
- \\
++ \\
++ \\
++ \\
++\end{array}$ \\
\hline
\end{tabular}


TABLE III

RATE OF DEATH OF N. GONORRHOEAE IN MEDIUM CONTAINING PENICILLIN AND KANAMYCIN

\begin{tabular}{|c|c|c|c|c|c|c|c|c|c|c|c|c|c|c|c|c|c|c|c|c|c|c|}
\hline \multirow{3}{*}{ Strain } & \multirow{3}{*}{$\underset{(\mu \mathrm{g} . / \mathrm{ml} .)}{\text { Kana- }}$} & \multicolumn{21}{|c|}{ Penicillin ( $\mu \mathrm{g} . / \mathrm{ml})}$. \\
\hline & & \multicolumn{7}{|c|}{$4 \mathrm{hrs}$} & \multicolumn{7}{|c|}{$6 \mathrm{hrs}$} & \multicolumn{7}{|c|}{$24 \mathrm{hrs}$} \\
\hline & & 1 & 0.5 & 0.25 & 0.12 & 0.06 & 0.03 & Nil & 1 & 0.5 & $0 \cdot 25$ & 0.12 & 0.06 & 0.03 & Nil & 1 & 0.5 & $0 \cdot 25$ & $0 \cdot 12$ & 0.06 & 0.03 & Nil \\
\hline \multirow{6}{*}{$\begin{array}{c}2 \\
\text { MIC } \\
\text { penicillin } \\
0.06 \mu \mathrm{g} . / \mathrm{ml} . \\
\text { kanamycin } \\
2 \mu \mathrm{g} . / \mathrm{ml} .\end{array}$} & 8 & & - & - & - & - & - & $(+)$ & & - & - & - & - & - & - & & - & - & - & - & - & - \\
\hline & 4 & & - & - & $(+)$ & $(+)$ & + & $+t$ & & - & - & - & - & $(+)$ & $+\dot{+}$ & & - & - & - & - & - & - \\
\hline & 2 & & - & $(+)$ & $(+)$ & $+t$ & $+t$ & ++ & & - & - & -- & + & ++ & ++ & & - & - & $\cdots$ & - & + & $+t$ \\
\hline & 1 & & $(+)$ & & & & ++ & ++ & & $(+)$ & $(+)$ & + & & & ++ & & - & - & - & + & & $+t$ \\
\hline & 0.5 & & - & $(+)$ & ++ & ++ & ++ & ++ & & - & $(+)$ & $+t$ & ++ & ++ & ++ & & - & - & $+t$ & ++ & ++ & ++ \\
\hline & Nil & & $(+)$ & + & ++ & ++ & ++ & ++ & & - & $(+)$ & $+t$ & ++ & ++ & ++ & & - & - & ++ & ++ & ++ & ++ \\
\hline \multirow{6}{*}{$\begin{array}{c}21 \\
\text { MIC } \\
\text { penicillin } \\
0.5 \mu \mathrm{g} . / \mathrm{ml} \text {. } \\
\text { kanamycin } \\
4 \mu \mathrm{g} . / \mathrm{ml} .\end{array}$} & 8 & - & - & $(+)$ & + & + & & + & - & - & - & - & + & & + & - & - & -- & - & - & & - \\
\hline & 4 & $(+)$ & $(+)$ & ++ & ++ & ++ & & ++ & - & $(+)$ & + & $+t$ & ++ & & $+t$ & - & - & - & + & ++ & & ++ \\
\hline & 2 & + & ++ & ++ & ++ & ++ & & ++ & $(+)$ & ++ & $+\div$ & ++ & ++ & & ++ & - & + & ++ & ++ & ++ & & $+t$ \\
\hline & 1 & $+t$ & $+t$ & ++ & ++ & ++ & & ++ & + & ++ & ++ & ++ & ++ & & $+t$ & - & $+t$ & ++ & ++ & ++ & & ++ \\
\hline & 0.5 & ++ & ++ & ++ & + & ++ & & ++ & + & ++ & ++ & ++ & ++ & & ++ & ++ & ++ & ++ & ++ & ++ & & ++ \\
\hline & Nil & ++ & $+t$ & ++ & +1 & ++ & & ++ & ++ & ++ & ++ & ++ & + & & ++ & ++ & ++ & ++ & ++ & ++ & & ++ \\
\hline
\end{tabular}

$++=$ Number of colonies similar to the original inoculum or increased.

$+=$ Reduced number of colonies.

$(+)=<10$ colonies.

Range of penicillin concentrations tested $0.5-0.03 \mu \mathrm{g} . / \mathrm{ml}$. for Strain 2.

$1.0-0.06 \mu \mathrm{g} . / \mathrm{ml}$. for Strain $2 \mathrm{i}$.

The result for the strains numbered 3 and 6 shows complete indifference: all the rest show an additive effect, in each case half the independent MIC of

TABLE IV

COMBINED BACTERISTATIC ACTION OF KANAMYCIN AND SULPHAFURAZOLE

\begin{tabular}{|c|c|c|c|}
\hline \multirow[b]{2}{*}{ Strain No. } & \multicolumn{3}{|c|}{ Drugs (MIC $\mu \mathrm{g} . / \mathrm{ml}$. ) } \\
\hline & Kanamycin & Sulphafurazole & $\begin{array}{l}\text { Kanamycin }+ \\
\text { Sulphafurazole }\end{array}$ \\
\hline 1 & 4 & 8 & $\left\{\begin{array}{l}2+0 \cdot 12 \\
1+4\end{array}\right.$ \\
\hline 2 & 2 & 8 & $1+1$ \\
\hline 3 & 2 & 2 & $\left\{\begin{array}{l}2+1 \\
1+2\end{array}\right.$ \\
\hline 4 & 4 & 2 & $2+0 \cdot 12$ \\
\hline 5 & 4 & $>8$ & $2+8$ \\
\hline 6 & 4 & 4 & $\left\{\begin{array}{l}4+1 \\
1+4\end{array}\right.$ \\
\hline 7 & 4 & 0.5 & $\left\{\begin{array}{l}2+0 \cdot 12 \\
1+0 \cdot 25\end{array}\right.$ \\
\hline 8 & 4 & $>8$ & $2+8$ \\
\hline 9 & 4 & 2 & $2+0.5$ \\
\hline 10 & 2 & 1 & $1+0 \cdot 25$ \\
\hline 11 & 4 & 2 & $2+0.5$ \\
\hline 12 & 4 & 4 & $2+2$ \\
\hline 13 & 4 & $>8$ & $2+8$ \\
\hline
\end{tabular}

one drug being potentiated by a sub-inhibitory concentration of the other.

\section{Trimethoprim and Sulphafurazole}

Trimethoprim (2,4-diamino-5- $\left(3^{\prime}, 4^{\prime}, 5^{\prime}\right.$-trimethoxybenzyl) pyrimidine) is a powerful inhibitor of purine synthesis at the stage next after that interfered with by sulphonamides, and the two drugs have been shown to exert a strongly synergic action. Its "spectrum" of activity is similar to that of sulphonamides, but with differences in degree: i.e. some species are more susceptible to trimethoprim than to sulphonamides and others vice versa. We have found, in studies to be reported elsewhere, that for an optimum effect the relative concentrations of the two drugs should be related to their relative activity against the organism, and this means that a fixed combination may not serve well for the treatment of all susceptible infections. $N$. gonorrhoeae is in fact decidedly less sensitive to trimethoprim than many other bacteria, and rather less so than to sulphonamides: hence, for the successful treatment of gonorrhoea, the proportion of trimethoprim in the combination should be large, or at least larger than that indicated for some other infections.

Bacteristatic Tests

Eighteen strains were examined. The minimum inhibitory concentrations of trimethoprim and 
sulphafurazole are given in Table $\mathrm{V}$ (overleaf). An example of the results obtained in tests of combined action is given in Table VI. Although 16 and $>4$ $\mu \mathrm{g}$. $/ \mathrm{ml}$. respectively of trimethoprim and sulphafurazole, acting alone, are required to prevent growth, combinations of 2 and 0.25 or 1 and $0.5 \mu \mathrm{g} . / \mathrm{ml}$. have the same effect, which is thus clearly synergic. An effect of this nature was seen in tests with seventeen of the eighteen strains.

TABLE V

NUMBERS OF STRAINS OF GONOCOCCI INHIBITED
BY DIFFERENT CONCENTRATIONS OF
TRIMETHOPRIM AND SULPHAFURAZOLE
\begin{tabular}{l|c|cccccccc} 
Drug & \multicolumn{8}{|c}{ Concentration $(\mu \mathrm{g} . / \mathrm{ml})}$. \\
\hline Trimethoprim & 1 & 2 & 10 & 4 & 1 & & & \\
\hline Sulphafurazole & & & 1 & 4 & 2 & 4 & 5 & 1 & 1 \\
\hline
\end{tabular}

TABLE VI

COMBINED BACTERISTATIC ACTION OF TRIMETHOPRIM AND SULPHAFURAZOLE

\begin{tabular}{|c|c|c|c|c|c|c|}
\hline \multirow{2}{*}{$\begin{array}{l}\text { Sulphafurazole } \\
(\mu \mathrm{g} . / \mathrm{ml} .)\end{array}$} & \multicolumn{6}{|c|}{ Trimethoprim ( $\mu \mathrm{g} . / \mathrm{ml})}$. \\
\hline & 16 & 8 & 4 & 2 & 1 & Nil \\
\hline $\begin{array}{l}4 \\
2 \\
1 \\
0 \cdot 5 \\
0 \cdot 25 \\
\text { Nil }\end{array}$ & $\begin{array}{l}\bar{z} \\
\bar{z} \\
\bar{z} \\
\bar{z}\end{array}$ & $\begin{array}{l}- \\
= \\
= \\
\overline{+}+\end{array}$ & $\begin{array}{l}- \\
= \\
= \\
\overline{+}+\end{array}$ & $\begin{array}{l}\bar{z} \\
= \\
= \\
++\end{array}$ & $\begin{array}{c}\bar{z} \\
= \\
\overline{+} \\
+ \\
+\end{array}$ & $\begin{array}{l}(+) \\
++ \\
++ \\
++ \\
++ \\
++\end{array}$ \\
\hline
\end{tabular}

The much greater activity of these two drugs in combination was also shown in plate dilution tests. Trimethoprim and sulphafurazole were incorporated in chocolate agar in concentrations differing 2-fold, and a third series was prepared containing mixtures of them in two different proportions. The results can be expressed briefly by saying that when one part of trimethoprim was added to nine parts of sulphafurazole the MIC of the latter was reduced from 8- to 32-fold (8-fold for six strains, 16-fold for eleven, and 32-fold for one). When one part of sulphafurazole was added to three parts of trimethoprim, the MIC of the latter was reduced 8-fold for two strains, 16-fold for eight, 32-fold for seven, and 64-fold for one. That so relatively small an addition of the second drug should have so large an effect on that present in the higher concentration is remarkable, and indicates a high degree of synergy.

\section{Bactericidal Test}

A test of combined bactericidal action was done, subcultures being made after $2,3,4,5,6$, and 24 hours. A progressive effect was observed, the nature and extent of which can be seen from the findings at three of these times (Table VII). The sulphonamide acting alone had no bactericidal effect whatever, the population remaining stationary or, in lower concentrations, increasing. Trimethoprim alone had a partial bactericidal effect in the two highest concentrations used. When the two drugs acted together, combinations of almost every concentration of each except the lowest had a progressive bactericidal effect which was detectable within 2 hours, substantial in 4 hours, and almost complete in 6 hours. Had subcultures been made after 8 hours many might well have been sterile: sterility was found at 24 hours.

In view of the conclusive result of this laborious experiment, which was entirely in accordance with expectation, it was considered unnecessary to repeat it with other strains.

\section{Discussion}

Of the three combinations examined, two appear to offer limited therapeutic promise or none, while the third is very promising indeed.

That the combination of kanamycin and penicillin has no synergic effect-and against some strains not even an additive effect-was disappointing. Five

TABLE VII

COMBINED BACTERICIDAL ACTION OF TRIMETHOPRIM AND SULPHAFURAZOLE

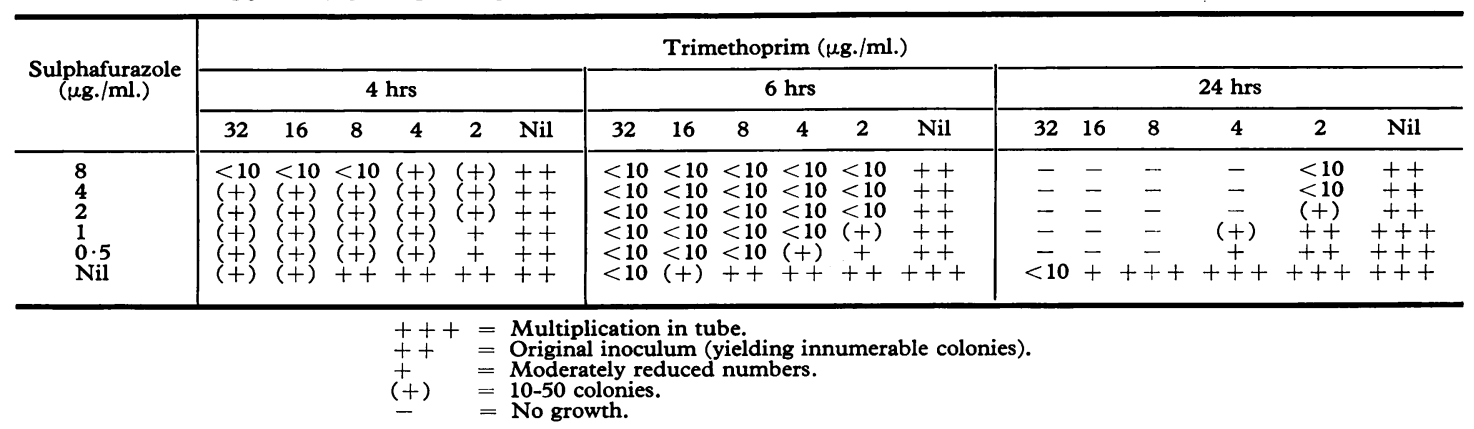


of the six strains against which the combination behaved indifferently were somewhat resistant to penicillin, and it is for such strains that the combination might have been useful. There is no indication for giving it a therapeutic trial.

This discouraging finding led us to re-examine by the same methods the action of this combination on Str. faecalis, about the clinical efficacy of which there can be no question (Garrod and Waterworth, 1962). This is not the place to report the results in detail, but they show in fact that combining these two antibiotics does not reduce the total amount required to inhibit growth or to exert some degree of bactericidal effect. The difference is that the combination is totally bactericidal, whereas after exposure to either antibiotic alone there are always some survivors. This difference distinguishes success from failure in treating endocarditis. It does not hold for the gonococcus, which is killed by either antibiotic alone: hence the absence of any synergy in action on this organism.

There are indications that the combination of kanamycin and a sulphonamide might have limited clinical usefulness. It might be possible to reduce the dose of kanamycin to $1 \mathrm{~g}$., which would be desirable for two reasons already stated, by giving a suphonamide in addition. This might be a single dose of a long-acting compound, the treatment thus not depending on the patient's co-operation in taking any further doses as instructed. The efficacy of such treatment would need to be verified by adequate clinical trial.

The combination of trimethoprim and a sulphonamide, on the other hand, shows a high degree of synergy. Moreover, this is evident not only in tests of simple growth inhibition, but in tests of bactericidal effect. It is well known that sulphonamides have only a bacteristatic action, and this is confirmed in the test described. The addition of trimethoprim converts this to a bactericidal effect, almost complete within a few hours and total within 24 hours. This is therefore a promising combination of drugs for the treatment of gonorrhoea, and good results from it have already been reported in this journal (Csonka and Knight, 1967).

\section{Summary}

The action of three drug combinations on gonococci has been tested in vitro, two of them being studied for bactericidal as well as bacteristatic action.

The combined action of kanamycin and penicillin is slightly additive on some strains and indifferent on others, particularly strains with increased resistance to penicillin.

Kanamycin and sulphafurazole usually have some additive effect: the addition of a sulphonamide might therefore enable the curative dose of kanamycin to be reduced.

Trimethoprim and sulphafurazole exert a strongly synergic effect in tests of both bacteristatic and bactericidal action.

\section{REFERENCES}

Cradock-Watson, J. E., Shooter, R. A., and Nicol, C. S. (1958). Brit. med. F., 1, 1091.

Csonka, G. W., and Knight, G. J. (1967). Brit. F. vener. Dis., 43, 161.

Garrod, L. P., and Waterworth, P. M. (1962). F. clin. Path., 15, 328.

Hooton, W. F., and Nicol, C. S. (1967). Postgrad. med. F., 43, Suppl. May. "The Clinical Aspects of Kanamycin": Proc. Conf. Royal Postgrad. med. School, London, 1966, p. 68.

Wilkinson, A. E., Race, J. W., and Curtis, F. R. (1967) Idem, p. 65 .

\section{L'action de trois combinaisons de médicaments sur les gonocoques RÉSUMÉ}

L'action de trois combinaisons de médicaments sur les gonocoques a été testée in vitro; deux d'entre elles ont été étudiées quant à leur action bactéricide et aussi quant à leur action bactéristatique.

L'action combinée de la kanamycine et de la pénicilline est légèrement additive sur certaines souches et indifférente sur d'autres, particulièrement sur les souches montrant une résistance accrue à la pénicilline.

La kanamycine et le sulfafurazole ont généralement quelque effet additif: l'addition d'un sulfamidé pourrait permettre alors la réduction du dosage curatif de la kanamycine.

La triméthoprime et la sulfafurazole exercent une forte action synergique quand leur action bactéristatique et bactéricide a été testée. 